\title{
Legal authority and savagery in judicial rhetoric: sexual violence and the criminal courts
}

\author{
David Gurnham' \\ School of Law, University of Manchester
}

\begin{abstract}
This article explores narrative devices in legal rhetoric, and the use of these devices for asserting the authority to distinguish lawful from unlawful inflictions of bodily harm. The argument made here is that the moral language adopted by judges in criminal appeal judgments on risky sexual and/or violent consensual acts embraces a set of interconnecting narratives otherwise observed in literature, and relating to gender, sexuality and race. I try to show how the reading of these legal cases is enriched by identifying these narratives, locating them as rhetorical strategies and reflecting on their uses in judicial decision-making. In particular, I argue that in the case-law explored here, these interconnected narratives are deployed in order to assert law's dominance over an imagined 'savage' other. Through this ongoing repudiation of savagery the distinctions between normative and nonnormative, violent and non-violent, lawful and unlawful are constructed.
\end{abstract}

\section{Introduction}

The character of the savage, who is unproductive, feckless and to whom civilised notions of morality and reasonableness are foreign, plays an important role in modern law's rhetorical assertion of its own authority and necessity (Fitzpatrick, 200I). The savage and the repudiation of savagery is perhaps most familiar as a literary dramatic device and has been identified particularly by postcolonial literary criticism. This article seeks to situate an intellectual crossing point between literature and law, using a reading of Shakespeare's The Tempest as a means of informing a critical perspective on an example of legal rhetoric. In the play, Prospero's authority over a tiny island community depends upon his successfully distinguishing his civilised rule from the savagery of his slave Caliban, who would usurp him and ravish his virgin daughter. The relationships of power at play there between virile European legal authority, rebellious sexual deviance, and vulnerable femininity, provides for a frame through which we can engage critically also with modern law. Modern judicial language rarely shows signs of quite such the dramatic struggle for moral or legal authority as that depicted in The Tempest. This is because the rhetorical quality of the means by which legal and moral plausibility of a judgment is secured will often be obscured by an ostensibly successful appeal to shared cultural or social concerns. ${ }^{2}$ However, there are occasions when the rhetorical nature of such appeals are dramatically and even violently exposed, particularly where a judgment relies for its force on legal moralism, such as those that have condemned certain dangerous or sexual practises as 'cruel' irrespective of the 'victim's' consent.3

I I am grateful to Daniel Monk, Ummni Khan, Suzanne Ost, John Harrington and Gary Watt for their helpful comments on earlier drafts of this article. Of course any errors remain my own responsibility.

2 For example the modern liberal concern to deter 'harmful' actions (Feinberg, I984).

3 By 'legal moralism' I mean the view that certain behaviours or ideas are held to be immoral in principle and accordingly criminalised. The reference to 'cruelty' relates to Lord Templeman's speech in $R v$. Brown [I993] 2 All ER 75 at 83 . 
Rhetoric relies for its persuasiveness on an audience sharing the assumptions made in the argument, or being sufficiently moved by the emotional force of the words used (Harrington, 2009). Therefore, given the sometimes rapid changeability of shared social attitudes towards sexual morality, overtly moralistic pronouncements both in and outside the courts about the acceptability or otherwise of particular sexual practices are particularly vulnerable to critical attention (Cranor, 1979). This article seeks to show that the moral rhetoric widely noted in the critical responses to older cases such as Donovan, ${ }^{4}$ Boyea ${ }^{5}$ and Brown ${ }^{6}$ continues to influence more recent legal judgment (such as the Court of Appeal decisions of $\mathrm{Dica}^{7}$ and $\mathrm{Konzani}^{8}$ ). The identification in these cases of deviant sexuality with 'violence' as a marker of self-evidently uncivilised conduct provides an opportunity for engaging in critical analysis of judicial rhetoric in which legal scholarship is informed and enriched by notions traditionally confined to the realms of literary and cultural studies. What I hope to provide here therefore is an engagement with the legal cases which demonstrates a particular application of interdisciplinary legal critique.

\section{Authority, normativity and savagery in The Tempest}

Let us begin then by exploring the ways in which narrative is used in literature to foster a sense of authority, and how this authority may be vulnerable to critique from a multidimensional approach to reading. Prospero is the patriarch of The Tempest: as a White European exile he rules a tiny island in which his subjects are his adolescent daughter Miranda, his servant Ariel and his "savage, deformed slave" Caliban. In order to maintain his authority over his subjects, Prospero must continually distinguish and repudiate the savagery of Caliban as failed or deviant male sexuality in contradistinction to his own authoritative and effective masculinity. This is a claim to authority that has very specific resonances with discourses on colonial power and resistance to it, but as I shall argue in the next section, it also has broader implications for a critical reading of modern law. For present purposes let me outline three interconnected aspects of this approach: (I) the emasculation of the non-normative by denying it the right to narrate for itself; (2) the sexualisation of that which is deemed to be non-normative; and (3) the emphasis of the vulnerability of that which is threatened by the non-normative, justifying condemnation and punishment.

First, Prospero assumes the right to himself to narrate an authoritative account both of Caliban's character and of the origins of his own rule on the island and how the order of things came to be. Prospero characterises his slave Caliban as a sexual menace and a source of physical and moral contagion, expressed by frequent allusions to disease, which are presented as consequent upon his racial status ("filth", "most lying slave", "hag-seed", "poisonous", "abhorred" (I.2), etc.). As Lamming puts it, Caliban seems in Prospero's eyes to have "pollution innate in his nature". ${ }^{9}$ The authority claim being made by Prospero is that Caliban is merely a misshapen, inhuman brute and as such must be condemned and enslaved. In the twentieth century, Caliban's evident struggle against Prospero's characterisation became a powerful metaphor for resistance to colonialism, and in my view the political struggle to narrate remains at the heart of any critique of legal

\footnotetext{
$4 \quad$ [I934] 2 KB 498.

5 [I992] I56 J.P. 505 (CA).

6 [I993] 2 All ER 75 (HL).

7 [2004] EWCA Crim II03 (CA).

8 [2005] EWCA Crim 706 (CA).

9 Lamming (2004, p. I60).
} 
authority. ${ }^{\text {Io }}$ Against Prospero's reduction of Caliban to mere "filth", Caliban asserts a sovereignty of his own, usurped by Prospero ("This island's mine my Sycorax my Mother, Which thou tak'st from me" (I.2. 470-7I). ${ }^{\text {I I }}$ However, Caliban lacks the power or the authority to convert this assertion of sovereignty into a narrative on equal terms with Prospero's. To the contrary, Prospero succeeds in ensuring that Caliban is prevented ever from being recognised as sovereign or independent person, but rather is held down as other to Prospero's European colonial narrative. The power to narrate events from one's own perspective and to diminish the narrative authority of conflicting accounts is a power that Prospero reserves for himself, which is denied to Caliban. Feminists have long identified the ability to narrate events as a site of political struggle for women in asserting their own identity against official histories and patriarchal worldviews, and scholars working in the shadow of Freud and Lacan have had to contend with the notion that language and the symbolic order itself is a predominantly male realm (Barnett, I998, p. I52). Ann Stoler highlights the interplay between race, sexuality and gender in producing a distinctly male perspective of colonial authority as quasi-sexual domination, in which the asymmetries of political power are reflected also in an Orientalist construction of race and sexuality in which "the Orient was penetrated, silenced and possessed". ${ }^{\text {I2 }}$ Colonial power rested on ensuring the "demasculinization of colonized men" - by associations with deviance or femininity - in contradistinction to the "hypermasculinity of European males". ${ }^{33}$ Prospero's exertion of masculine dominance and control over Caliban (as well as the other characters of the play - his servant Ariel and his daughter Miranda) is the archetypal colonial "male power fantasy" in which "racial distinctions were fundamentally structured in gendered terms", with the powerful European coloniser very much 'on top'. These are the racial and gender dimensions of a theory of authority - including the authority to condemn and punish - that, in the next section of this article, I shall argue informs judicial rhetoric in the criminal appeal judgments on consensual sexual behaviour that causes bodily harm (Fitzpatrick, I999, p. 40). ${ }^{\text {I4 }}$

Second, the threat of the savage is constructed in terms of sexual deviance and excessive desire. Like the syphilitic prostitute of the nineteenth-century European imagination, Caliban's 'pollution' is made all the more dangerous by the fact that he is inherently and unalterably Other to the moral codes of his civilised European masters. ${ }^{15}$ The most serious offence that we hear of Caliban attempting is the 'violation' of Prospero's virgin daughter Miranda, which Prospero uses to justify imprisoning him:

I have used thee,

Filth as thou art, with human care, and lodged thee

In mine own cell, till thou didst seek to violate

The honour of my child. (I. 2. 344-47)

Io Hulme (I986, pp. I I4-25), Said (I994, pp. 256-57).

I I To this claim over the land taken from Caliban, Prospero offers no convincing reply, except that he is a "most lying slave”. Hulme describes Prospero's accusations as "vague” and "somewhat hysterical” (Hulme, I986, p. I24).

I2 Stoler (2002, p. 44), quoting Said (I978, p. 207).

I3 Stoler (2002, p. 46).

I4 Fitzpatrick argues: "There is an insistent impossibility of relation, an incommensurable divide between the peasant and the court." See also Mannoni (I956, p. II7), who argues that Prospero's hatred of Caliban (and hence colonialists' hatred of their colonised peoples generally) is a defensive reaction to the realisation that Caliban regards himself as "a person in his own right" with his own "desire for freedom".

I5 On the dangers of syphilitic prostitutes for European men in colonial discourse, see Stoler (2002, pp. 48-49). 
It is Prospero who narrates this event, and it is not clear from the text whether we read 'violation' as a rape in the modern sense of intercourse without consent or simply impudent sexual overtures which according to prevailing colonial attitudes would be treated as an outrageous insult by any selfrespecting White European, and often not distinguished in law from a sexual assault (Hulme, I986, p. I26, Mannoni, I956, pp. I IO-II). ${ }^{\text {I6 }}$ Again, exposing the stereotype of 'native' sexuality as deviant and dangerous is one that, in the twentieth century, took on great political significance in challenging the foundations of colonial authority. This is evident both from uses of this scene in critical literature, ${ }^{17}$ and also in twentieth-century productions of The Tempest, which played on European anxieties about the interconnections between race and sexuality. ${ }^{18}$ Again however, there is a broader significance in the sexualisation of savagery in asserting moral and legal authority to condemn and to punish.

Third, legal and moral authority is secured against savagery through an appeal to the feminine, in particular showing how vulnerable White femininity must be protected from being contaminated and degraded. Whether an attempted rape or not, Caliban's response to Prospero's accusation seems to align him with Prospero's characterisation of him as an uncivilised deviant with no sense of sexual propriety, thus implying an acceptance of the European's authority: "O ho, O ho! Woulds't had been done!/ Thou did prevent me; I had peopled else/ This isle with Calibans" (I.2. 348-50). This is swiftly followed with a sharp rebuke, which I would like to draw attention to in developing my argument about the gendered nature of legal authority. ${ }^{19}$ It is the identity of the character who delivers that rebuke that is significant for these remarks about the gender of authority and of innocence. In the First Folio of 1623 it is clear that it is the girl Miranda who, apparently unfazed by Caliban's naked lust, responds by scolding Caliban and reminding him to know his place. However, twentieth-century editors of The Tempest would not allow her to speak these authoritative, unfeminine words, placing the speech instead in the mouth of the more naturally authoritative Prospero, effectively silencing Miranda and forcing her to sit passively by, apparently having nothing to do with the coarse language being used about her. ${ }^{20}$ In other words, the originally assertive and tomboyish Miranda was civilised according to the norms of respectable White femininity by the Tempest editors until her post-colonial re-emergence because, whether by deliberate doctoring or an unwitting error that somehow became orthodox, to have

I6 Ann Stoler describes how the protection of White women from sexual assault became an "obsession" for European settlers, and justified maintaining White supremacy and segregation with severe punishments for immoral sexual acts (i.e. sexual activity between native men and White women) (Stoler, 2002, p. 25). Franz Fanon describes the anxiety amongst French colonialists in the middle of the twentieth century: that without legal prohibitions the 'naturally' promiscuous Black Africans "will flood us with little mulattoes". Whichever historical account is applied, it is an anxiety about (in Fanon's words) "a genital potency beyond all moralities and prohibitions" that informs political and moral discourse (Fanon, I986, pp. I58, I77). Fanon himself does little to soothe such anxieties, warning that the colonised man dreams of "possession: to sit at the settler's table, to sleep in the settler's bed, with his wife if possible", and also of "action and aggression ... to exchange the role of quarry for that of the hunter ... to become the persecutor" (Fanon, I963, pp. 32, 4I-42). Fanon characterises the colonial view of colonised peoples as "insensible to ethics ... the negation of values ...the corrosive element ... disfiguring all that has to do with beauty or morality” (Fanon, I963, p. 34).

I 7 Hutchinson draws similar parallels between the abuse of slaves as 'breeders' and modern reductionist views of Black male sexuality as dangerous to White women, and of Black women as promiscuous (Hutchinson, I999, pp. 8I-86).

I8 In Peter Hall's I988 National Theatre production, Caliban appeared "naked apart from a rectangular box restraining his penis; it was fastened by two belts and padlocked onto his body, much of which oozed blood” (Dymkowski, 2000, p. 69).

I9 “Abhorred slave, Which any print of goodness wilt not take, Being capable of all ill!”... etc.

20 Compare, for example, Shakespeare (I954) edited by Kermode for the Arden Shakespeare series with that of Shakespeare (2000) edited by Vaughan and Vaughan for the third Arden series. 
allowed Miranda to answer Caliban back so fearlessly on the question of a sexual violation would have involved her too closely in the alleged act, and thus with an uncivilised desire. ${ }^{21}$ It would have implied that Miranda herself understood such a savage and deviant sexuality, implying (albeit obliquely) that she might harbour less than fully acceptable sexual desires of her own. To associate the virgin daughter of the noble Prospero with savagery would have been to fatally undermine the moral coherence of the play and Miranda's credibility as a victim requiring patriarchal assistance, at least for colonial audiences who could be expected to have shared the traditional perceptions of 'Black' sexuality described above.

In one sense, the editing of The Tempest in this way is reminiscent of the horrifically violent events played out in the much earlier play Titus Andronicus. In that play, the daughter of the noble Roman general (and one-time possible candidate for emperor) Titus is raped and mutilated by the sons of the Goth Queen, whose motivation seems to be both sexual and political. Lavinia has her "sweet tongue" cut out and her "lily hands" lopped off so that she cannot speak or write the names of her abusers. ${ }^{22}$ In brutally literal terms, Lavinia's own narrative is silenced, and her more naturally authoritative father is left to speak for her. As in The Tempest, the politico-legal significance of the crime is that it is treated as a challenge to moral and legal order itself, using the silenced, abused female body as symbolic of the vulnerable state. Being physically prevented from narrating her own story, Lavinia maintains a crucial distance between herself as symbolic of endangered purity and brutal savagery. Likewise, a feminine Miranda who allowed her father to speak about her violation for her is one that betrays no sign of (and thus no hint of complicity with) the savagery that marks the deviant Caliban. In the anxiety to distinguish civilised femininity from savage masculinity it is possible to begin to appreciate the interplay between gender and racial narratives. While Miranda is subject to feminisation according to the stereotype of civilised, White femininity (i.e. a vulnerable White virgin of good breeding in need of protection by a strong patriarch), Caliban is also emasculated in the sense of being reduced to a failed sex offender and an outsider to civilised norms.

Caliban's savagery lies in the excessiveness of his sexuality, infectiousness and the chaos that he represents. However, an important aspect of Prospero's treatment of Caliban is that his own response to Caliban threatens to veer into excessiveness, and in this way risks blurring slightly the apparently clear line between civilised and savage. Apart from the general tirade of abuse that Prospero constantly aims at Caliban, the latter's attempted violation of Miranda is the only specific crime for which Prospero justifies Caliban's confinement and slavery, and thereby his emasculation and disempowerment. Given that the precise nature of his 'violation' is not made clear, the consequence of learning about it through Prospero's condemnation and punishment only confirms the degradation he already suffers as a 'misshapen' slave who must fetch firewood and catch fish, etc. for his master. ${ }^{23}$ In other words, even if the specific instance of sexual threat were not reported, the characterisation of Caliban as dangerous savage would not be diminished.

2I As a White female adolescent, Miranda lacks the natural authority to speak about savage desire without becoming compromised by it, unlike Prospero. Other critics have commented that colonial authority depended upon a natural and self-evident racial boundary between colonised and colonisers, which Miranda is as yet not competent to ensure (Stoler, 2002, p. 42). George Lamming's own post-colonial reading of Miranda sought to suggest that Miranda was so compromised: "at the ripe and provocative age of fifteen, a virgin and, like her father, curious about the facts of life” (Lamming, 2004, p. I56).

22 The references to Lavinia's abused body are made by Marcus Andronicus, whose lament has been interpreted as using the violated White female body as a metaphor for treason (see Raffield, 2008, pp. 2I4-I5, and Gurnham, 2009, pp. 172-74). Ann Stoler (2002, p. 34) describes how the killing of a White woman in colonial Java was similarly treated as an act of subversive political agitation, justifying a military response.

23 On this analysis, Caliban as slave, failed sex-offender and racially other are all interconnected attributes that mark him as savage. As Ann Stoler writes, sexual control of supposedly sexually amoral natives was "a fundamental class and racial marker implicated in a wider set of relations of power" (2002, p. 45). 
Whether or not we 'in fact' believe that Caliban sexually violated Miranda in a modern sense, his degraded moral and physical status as Prospero narrates it ensures that he is to be regarded as a menace to civilised society. As I will explore in more depth in the next section, the construction of savagery in legal rhetoric is achieved similarly by conflating facts 'in fact' and 'facts' as they are imagined in judicial narrative.

\section{Savagery and civilisation in judicial rhetoric}

The preceding discussion explored ways in which moral and legal authority was claimed and maintained in The Tempest by distinguishing savagery from the civilised through a set of interconnecting narratives about race, gender and sexuality. The reduction of the Other to a stereotype of failed deviant masculinity, and the distancing of it from the civilisation that it threatens, is most obviously identified in colonial discourse and resistance to colonial authority, as Fanon says: "As every man climbs up towards whiteness and light, the European has tried to repudiate this uncivilized self." ${ }^{24}$ I want to show now some ways in which modern legal rhetoric also makes use of this relationship of repudiation to secure its own authority to distinguish and condemn non-normative behaviour. Scholars such as Peter Fitzpatrick have already produced critical analyses of the intimate relationship between law and savagery in general terms, of law "emerging from savagery" which could "know, absorb, and deracinate the savage impulses", and the existence of savagery "constantly at the frontier" thereby "negatively provides the content of [Western, civilised] identity". ${ }^{25}$ Building, as Fitzpatrick does, on a Derridean perspective, involves emphasising the inextricability of law and savagery (Derrida, I992). This article must restrict its scope only to a specific instance of this relationship, and focuses on the judicial rhetoric used across a span of cases that make an explicit appeal to legal moralism. However, it is the work of repudiating civilisation's savage 'other' in legal language as identified by Derrida and by Fitzpatrick that I want to explore here. Jasbir K. Puar does this in the context of contemporary political discourse, and a brief account of his identification of the relationship of repudiation between law and savagery gives an indication of the sort of legal analysis this article will adopt. Puar explores how discourses in the United States on Islamic terrorism also construct a binary relationship between the civilised and the savage by a sexualisation of a racially other threat. In the same way that Prospero's justification of his own authority to subdue and subordinate Caliban depends upon him identifying the latter as a libidinous savage, Puar seeks to argue that the combined response from both conservative 'hawks' and also apparently progressive commentators to Islamic terrorism has sexualised the threat in terms of discourses of Orientalist deviancy (Puar, 2007). For Puar, 9/I I was perceived in America not merely as an act of violence, but also as a traumatic "sexual violation" (Puar, 2007, p. 4I), the "evilness" of Osama bin Laden accentuated "through associations with sexual excess, failed masculinity (i.e. femininity) and faggotry" (p. 46), and Muslim terrorism generally in terms of pathologised and racialised perversity (p. 5I). Puar's argument is that sexuality is relevant to terrorism discourse because of conservative and feminist readings of Islamic terrorism as an extreme emotional reaction to US global hegemony that is experienced as sexual humiliation (p. 58). In its violent response to foreign terrorism, the American nation found strength in the moral superiority of both heteronormativity and homonormativity that are both "bound to whiteness" (p. 32). 'Acceptable' homosexuality (monogamous, family-oriented) became aligned with US exceptionalism through the legalisation

24 Fanon (1986).

25 Fitzpatrick (I999). See also Fitzpatrick (200I, pp. 73-84). 
of gay marriage, ${ }^{26}$ and also by American rights campaigners. The latter Puar accuses of capitalising on racist sentiments after 9/I I, for example feminists who identified "Islamic fundamentalism as the single greatest violent threat to women” (p. 6), and gay rights groups such as Outrage! who campaign against the homophobia of sharia law (p. 138). And it was the perceived pathological degree of homophobia amongst Muslim terrorists that allowed, according to Puar's understanding at least, the humiliation of prisoners at Abu Ghraib to be explained by the fact that homosexual acts were themselves illegal under Islamic law (p. I38).

I see the value of Puar's work as exploring ways in which the narratives of race, gender and sexuality discussed in the previous section may inform a critical method. His critique of sexualised political discourse in the US after $9 / \mathrm{I}$ I builds on the social and cultural contingency of law's separation from savagery. Puar highlights a specific instance of the interplay between race and sexuality and consequently an apparent distinction between civilised and savage violence. Bringing the focus down to judicial discourse, in this section I examine the criminal appeal cases on the extent to which a person may give lawful consent to dangerous and potentially harmful activities, looking in particular at Donovan, Boyea, Brown, Wilson, Dica and Konzani. My discussion focuses on the ways in which the courts claim and maintain the authority to condemn ostensibly private consensual behaviour as dangerous and illegitimate uses of violence that are necessarily outside the bounds of law, and this section does this with reference to the same interlocking narratives of sexuality, race and gender identified above in The Tempest. The discussion of criminal appeal judgments that follows is not intended to establish that the English courts are guilty of any concerted discrimination, but in seeking to uncover implicit racial and gender narratives there is necessarily a claim made that there are some worrying implications to be drawn from judicial language. As with other multidimensional approaches to legal critique, the reading I offer here of the relevant criminal appeal cases involves drawing particular connections between themes identified in literary criticism and judicial language.

\section{The 'serious violence' cases: racial and gender narratives in distinguishing 'cruel' from 'incidental' inflictions of bodily harm}

The line of judgments through Donovan, Boyea, Brown, Dica and Konzani collectively provide what is currently regarded as the legal distinction between those activities that are always deemed criminal irrespective of the victim's consent, and those that may be lawful provided that the 'victim' consented. Where any bodily harm is involved, the crucial distinction that has emerged is that between acts which are by their nature violent and for which bodily harm seems to be too central to the activity to allow consent to apply, and those in which bodily harm can be dismissed as incidental or accidental consequences of lawful activity, where consent is not so excluded even if the activity might seem to involve violence. Given that in both cases the courts are seeking to pass judgment on consensual behaviour the distinction is inevitably a difficult one to justify objectively, and accepting its coherence as drawn in the cases requires one also to accept the legal moralism that informs it. The current violent/non-violent distinction has developed from an arguably broader test established in Donovan. In that case, Swift J ruled that if the violence used by a defendant is such as to make bodily harm a "probable consequence", ${ }^{27}$ then the act in question is "in itself a criminal act" irrespective of consent. ${ }^{28}$ Swift J allowed for "well established exceptions", i.e. violence that in his view was not real violence (i.e. rough horseplay conducted in

26 Puar describes gay marriage as "yet another marker in the distances between barbarism and civilization" (2007, p. 20).

27 [I934] $2 \mathrm{~KB} 498$ at 507.

28 [I934] $2 \mathrm{~KB} 498$ at 507. 
a spirit of friendship and 'properly conducted' games and sports including boxing). In AttorneyGeneral's Reference, Lord Lane CJ expanded this point, adding that consensual bodily harm was only to be regarded as a criminal act when inflicted "for no good reason". ${ }^{29}$ In Boyea it was agreed that the authorities taken together meant that an inherently unlawful act meant "an assault intended or which is likely to cause bodily harm", adding that the presence of "indecency" as the parties' motivation might indicate that there was 'no good reason' and thus a crime committed. ${ }^{30}$ The majority of the House of Lords in Brown agreed that, since sexual expression/gratification had not previously been regarded as one of the "well-established exceptions" (Donovan) or a "good reason" (Attorney General's Reference) to this general prohibition set out in Donovan, Brown, Laskey and Jaggard, etc. were guilty of offences under s.47 and s.20 of the Offences Against the Person Act I86I irrespective of consent. Lord Templeman succinctly captures the emerging coalition between violence and sexual depravity in the legal test when he states: "In principle there is a difference between violence which is incidental and violence which is inflicted for the indulgence of cruelty." ${ }^{\text {I }}$ Unlike the violence used in say, rough and undisciplined horseplay or in boxing, violence used for sexual gratification is 'cruel' (and hence unlawful notwithstanding consent), because instead of using violence for a more laudable end, the effect of sado-masochism (SM) is simply to "breed and glorify cruelty" itself. ${ }^{32}$

Cases since Brown that have tackled the question of injuries sustained during sexual activity have read Brown as requiring that any use of force for sexual motivation, together with an appreciation by $\mathrm{D}$ that some injury might result, be regarded as cruel, i.e. unlawful violence. Thus, the conviction of a man for inflicting fatal injuries on his girlfriend during sexual activity in Slingsby ${ }^{33}$ was quashed because "the deceased sustained her unfortunate injuries not when she or the defendant were consenting to injury, but as an accidental consequence of the sexual activity which was taking place with her consent”. ${ }^{34}$ Given its physical nature, vigorous sexual activity will often carry certain risks of injury, but where no bodily harm is anticipated this is distinguished from exposing others to a risk intentionally or recklessly. Such acts are therefore not "violent" in the pejorative sense used in Brown. At first look this might seem to widen the scope of consent and allow it to operate where it was denied in the earlier cases. However, this is not so: Judge $J$ in Slingsby makes it clear that if at the relevant time the parties did so much as turn their minds towards the possibility of bodily harm occurring, and nevertheless continue so to act, then bodily harm that results cannot be dismissed as "accidental", and they have in fact crossed the line into 'violence' and 'cruelty'. This is surely a very fine but very significant line when considering sexual behaviour especially: where injuries are inflicted within the contemplation of consenting parties in the course of 'lawful' activity such as horseplay, the fact that D contemplated some injury will not lead to criminalisation. But since sexual gratification is not a recognised exception to the general criminalisation of contemplated bodily harm (and indeed in Brown Lord Lowry had specifically warned of the dangers of "the powerful influence of the sexual instinct"35), consent only applies in cases such as Slingsby in which the bodily harm was a freak accident. As I discussed in the previous section of this article, when situated this way in discourse, sexualisation

\footnotetext{
29 [I98I] QB 7I5 at 7I9D.

30 (I992) I56 JP 505 at 5 I3

3 I [I993] 2 All ER 75 at 83.

32 [I993] 2 All ER 75, per Lord Templeman. On horseplay see $R$ v. Jones (Terence) (I986) 83 Cr App R 375.

33 [I995] Crim LR 570.

34 [I995] Crim LR 570, per Judge J. Also held in $R$ v. Meachen [2006] EWCA Crim 24I4 at para [40]-[43].

35 [I993] 2 All ER 75 at 99.
} 
is key in the identification of savagery. It is this association between violence and sexuality and the consequent narrative of civilisation repudiating savagery in legal rhetoric that I now wish to focus upon.

Distinguishing acts that are directed towards violence itself - and thus towards a self-evidently negative, unproductive end - from acts directed to some positive end such as "perfect friendship" (Donovan), appeals to a set of 'common-sense' cultural assumptions about violence and its relationship to sexuality. ${ }^{36}$ Other commentators have drawn attention to the cultural contingency of distinguishing consensual acts by such an appeal, arguing that in characterising sexual acts carried out by consenting adults who do contemplate the infliction of bodily harm merely as violence, fails to grasp that, just as in boxing and horseplay, there is also a social and cultural meaning to the violence used by sado-masochists (Athanassoulis, 2002).37 But as I argued in the first section of this article, the power to narrate the meaning or non-meaning of an act or behaviour and to inscribe it as dangerous or deviant is central to law's authority claim, and therefore any failure on the part of the judges in this regard should not be dismissed as mere ignorance or oversight. In describing sado-masochism not as an expression of sexuality but merely as cruel violence, the majority of the House of Lords in Brown removed from the defendants any possible claim to a right to private expression of sexuality (Moran, I996, p. I8I). ${ }^{8}$ Furthermore, the word 'cruel' inevitably carries with it certain social and cultural connotations, especially when it is associated with sexual behaviour and norms. At its most general level, what unites all of those activities deemed lawful when performed with consent is that they are believed to be consistent with 'civilised' society because any harms resulting may be dismissed as unfortunate accidents that sometimes happen. Cruelty on the other hand, especially when fuelled by sexual desire, by its very unpredictable nature tends to be regarded as not so compatible. The idea that someone would deliberately go out of their way to inflict bodily harm for its own sake is savage and foreign to civilised sensibilities; it is excessive, frightening and driven by passions that are difficult to control and legitimately marginalised (Moran, I996, pp. I82-85). As has been discussed elsewhere, the speech of Lord Templeman in Brown is particularly notable for his moral rhetoric on sado-masochism, using extreme pejorative expressions such as "barbarity", "evil", "cult" and "uncivilized".39 Heightening the impression of SM as a primitive sacrificial ritual, Lord Jauncey describes the "free flow of blood", raising the prospect of HIV transmission, as well as the details of genital torture by burning, nailing and cutting. $4^{\circ}$ Lord Lowry asserted that in SM there was an "inevitable threat of Aids", ${ }^{\mathrm{I}}$ a claim reinforced by Lord Templeman, who revealed that one member of the group later did die of Aids. ${ }^{42}$ As has been well observed elsewhere, these

36 On the deployments of rhetoric in argument see generally Booth (2004, pp. 55-66).

37 Athanassoulis (2002, pp. I 52ff) argues that the Lords should have treated sado-masochism, not as a violent act (and thus unlawful), but rather "as a sexual act which happens to be expressed through violence" (and thus lawful). See also Stychin (I995, p. I2 I).

38 For the application of Article 8 in conferring a right to private sexual expression, and in particular the Art 8(2) exception which permits public interference "for the protection of health or morals", see Laskey, Jaggard and Brown v. United Kingdom, 24 Eur. H.R. Rep. 39 (I997).

39 [I993] 2 All ER 75 at 82 and 84. For a detailed critique of their Lordships' condemnation of homosexual sadomasochism, see Moran (I996, pp. I80-9I) and Stychin (I995, pp. I I7-39). For a brief overview of the use of the concept of 'evil' in the common law see Ramage (2008).

40 [I993] 2 All ER 75 at 9I-92.

4I [I993] 2 All ER 75 at 99.

42 [I993] 2 All ER 75 at 83. At 99 it was conceded that the death was unrelated to the events in question. It was accepted that all equipment had been properly sterilised, and the Aids death was unrelated to the sadomasochism. However, as Stychin has pointed out, the safety measures seem only to have confirmed in their Lordships' minds that the risks of contagion and loss of control were real (Stychin, I995, p. I22). 
assertions are not in themselves given to precise meaning in legal terms or empirical demonstration. For example, Stychin argues that Lord Lowry's suggestion that Aids is an "inevitable" threat in this context portrays the gay body as intrinsically contagious (Stychin, I995, p. I26), fusing in rhetoric the physical risk of disease and the moral risk of contagion (p. 136), and reinforcing the traditional association between homosexuality and dangerous depravity (p. I35). Moran likewise attaches significance to ways in which the Lords' rhetoric implies that the sado-masochistic violence at issue in this case is marked in the judicial rhetoric by contagion, unruliness and unpredictability - both in physical and in moral terms. ${ }^{43}$ I would take this analysis a stage further by suggesting that the assertions as to uncontrollable danger and especially an inevitable relationship between SM and the risk of Aids deploy a rhetorical strategy known to rhetoricians since classical times as logos, whereby the speaker or writer resorts to commonplace assumptions that the listener or reader is presumed to be able to relate to (Booth, 2004, p. 6I).44 Such a narrative resorted to by the judges in this case is not merely an effort to marginalise an unsavoury or dangerous sexual practice, but furthermore an illustration of the immense rhetorical effort considered necessary to establish the externality of the savagery that threatens civilised society. ${ }^{45}$

As well as behaviour to be regarded as anathema to law's own (regulated, civilised, reasoned, controlled) violence, the allusions to the 'savagery' of the sado-masochism, its ritualistic excess and the risks of infection may also be interpreted as racially constructed. Post-colonial critics have argued that sexuality is the crucial marker of Otherness, and is to be found, as Stoler puts it, "in any racist ideology". ${ }^{6}$ Although I do not make any accusations of judicial racism as such, the discussion that follows seeks to argue that the narrative of savagery in identifying an act as illegal does indeed depend on interlocking negative presumptions about race, gender and sexuality. To associate homosexual sado-masochism with the risks of HIV transmission and unbounded physical dangers irrespective of the actual facts is to invoke a then very common stereotype relating both to sexuality and race. It is well documented that the fear of disease generated by such concerns for the permeability of national borders and their vulnerability to foreign invasion/ infection has a productive role in terms of the 'civilised' self-identity of Western nations. ${ }^{77}$ In the I980s and I990s particularly, HIV/Aids was widely believed to have been brought to the UK and other Western countries from Africa, by a network involving primitive contraceptive methods among Africans (i.e. anal sex), female prostitutes acting as incubators of the infection and promiscuous Western homosexuals who might have 'tried' heterosexual intercourse with an infected prostitute and then begun spreading it about with the abandon assumed to be common to the typical gay man (Treichler, I988, pp. 45-52).48 At the time at which the Brown judgment was handed down by the House of Lords, health (infectious diseases) and sexuality were very much racial issues in social and political discourse (Martin, I994). In her account of popular representations of the human immune system at the time of Brown, Emily Martin identifies a wealth of metaphors relating to defence and race that illuminate this point. She describes how the

43 Moran (1996, pp. I82-83).

44 See also Harrington (2009, p. 319).

45 For an example of the homophobia charge, see Sithamparanathan (2002, p. I 86). See also Moran (I996, p. I 85), who draws attention to the repeated invocation of "homosexual sadomasochism" as connoting the marginality and dangerousness of the acts in question.

46 Stoler (2002, p. 46).

47 Darian-Smith notes that the prospect of an influx of disease-bearing agents into Britain by the opening of the Channel Tunnel, may have served to strengthen European identity in the I99os (Darian-Smith, I995, pp. 86 - 87).

48 See also Gilman (I988, p. 99) and Bersani (I988, pp. 2 IO-I2). 
onset of the HIV/Aids crisis in the early I980s created a new interest in representations of the immune system in the media. ${ }^{49}$ According to the new world view post-Aids, the immune system in the popular imagination came to be associated with national immigration control, defending the body imagined as a nation state, by distinguishing between "self" and "non-self", and the part understood to represent 'non-self' predictably characterised as "foreign and hostile". ${ }^{\circ}$ Reviewing treatments of the subject in the I980s, Martin notes that those hostile 'non-self' elements tended to be referred to in popular science literature using such expressions as "the threatening horde" 5 r and "illegal aliens". ${ }^{2}$ A certain type of white blood cell (the macrophage) whose function seems to be to 'eat' foreign cellular material, is described in one medical text from the I980s as "cannibal [istic]", and Martin infers from this description an impression of these cells as "barbaric and savage in their willingness to eat any manner of thing at all".53 Martin's attention to the language of scientific discourse - a form of description traditionally (though often without justification) reserving for itself considerable authority as objective - is an important link between the racial dynamic of the spread of HIV as a form of savage threat to civilised society and the criminal courts.

In pursuing a multidimensional approach, the relevance of sexuality may also be explored in relation to gender, and the feminisation of both defendant and victim in these cases. With regards to the defendant, the gender narrative is one that emphasises the non-normativity of the male behaviour in question with a form of female perversion. Remaining with the references to HIV a little longer, Lord Templeman's and Lord Jauncey's suggestion that the parties in the case were so reckless as to endanger both their own life and the lives of many others connects with a stereotype common at the time, of the 'typical' gay man whose addiction to perversity led him to an almost "suicidal" degree of promiscuity (Bersani, I988, pp. 210-I2).54 This was and is a view that echoes the nineteenth-century belief that both the source and spread of syphilis was the responsibility of deviant female sexuality - namely prostitutes that seduced and distracted otherwise respectable men (Treichler, I988, p. 45).55 The association of the gay body with that of the deviant female prostitute, coupled with the widely held belief (encouraged in scientific publications in the early I980s) that it was only possible to spread HIV through anal intercourse, entrenched a gendered and heteronormative view of Aids. On this view, women could not be active transmitters of HIV unless they were deviant to the extent that their sex life was - as Treichler puts it - "quasi-homosexual", i.e. engaging in anal intercourse with large numbers of men. ${ }^{6}$ Of course, the belief that HIV/Aids is spread only through anal intercourse has not lasted, but there is ample evidence that the homophobic/sexist popular association between the sexually deviant woman and the 'typical' gay man (both as masochistically immoral) still operates (Dean, 2000). On this point racial and gender narratives come together: the stereotype of the sexually deviant woman is most deeply embedded within racial and Orientalist stereotypes of promiscuous women of colour. Colonial stereotypes of the early nineteenth century played on the exoticness and consequent excitement and danger - of colonised women and the excessiveness of their sexuality. As Ann Stoler explains, literature produced for consumption by colonial elites made

\footnotetext{
49 Martin (I994, pp. 5I-53).

50 Ibid., p. 53.

5 I Ibid., p. 53, quoting Schindler (I988, p. I3).

52 Ibid., p. 54, quoting Nilsson (I985, p. 2I).

53 Ibid., p.56.

54 See also Stychin (I995, p. I26).

55 See also Gilman (I988, p. 99).

56 Treichler (I988, p. 49).
} 
ample use of "lurid descriptions of sexual license, promiscuity, gynaecological aberrations, and general perversion marking the Otherness of the colonized". ${ }^{57}$ Hutchinson has argued that such stereotypes of 'Othered' promiscuity has led to a devaluation of Black female experience both in legal institutions and in (White-focused) feminist political movements. $5^{8}$ Feminist scholars have previously noted that depictions of savage femininity have been used negatively to distinguish civilised (masculine) culture. Barnett, for example, refers to the Furies of the ancient Greek dramas depicting the murder of Clytemnestra by her children Orestes and Electra. These creatures of revenge that pursue murderers on behalf of their victims, that Euripides' Orestes describes as the "priestesses of the dead, goddesses of terror" with "dog-faces and gorgon-eyes", are read by feminists as symbols of a primordial feminine world before civilisation. 59 The Furies are finally banished by Apollo in Aeschylus' The Orestia and are superseded by a court of law founded not on bloody savage revenge but rather on principles of reason, argument and persuasion. Barnett describes this as the "founding moment of patriarchy". ${ }^{60}$ In these ways then, uncivilised sexual deviance has long been associated with a racialised and a gendered threat to civilised health and morals and the majority judgment in Brown may be read accordingly.

In order most forcefully to identify the non-normative with the savage, legal rhetoric of the kind used in Brown also demonstrates another rhetorical strategy. Treating both actual and possible consequences of SM as equally serious, their Lordships referred to terrible injuries that did not actually occur, to blood-born diseases that were never transmitted, and to widespread corruption that never took place. These are nightmarish scenarios that take place only within the judicial narrative. They imply an emotional appeal - a strategy of persuasion known to rhetoricians as pathos - to bear in mind the victims of the sadistic conduct, both that featured in the case itself and also other potential victims that might have been corrupted had the group not been interrupted by the police. ${ }^{6 r}$ A consequence of this effort, however, is that the rhetoric used by the Lords arguably embraces some of the excessiveness of passion and violence that it condemns, and thereby risks being seen to lose some of the moral high ground. Critics adopting post-structuralist critical approaches have long argued that law and legal judgment never really occupied moral high ground in any logical or ultimately justifiable way. Derrida, for example, argues that law is always deconstructable as an ultimately arbitrary moment of violence through which it asserts its own authority over that which it seeks to subdue (Derrida, I992). However, in order to maintain a semblance of distance between law and savagery, law's violence must be shown to be only reluctantly inflicted, and within legitimate and clearly demarcated limits (Derrida, I992, pp. 33, 35). ${ }^{62}$ The risk that law should be perceived to be infected by the very excesses of passion that Brown condemned has prompted subsequent appellate judges to rein in the more obviously controversial (i.e. the most difficult to present as universal common sense) aspects of its rhetoric. ${ }^{63}$ It has also led academic commentators to challenge the logic of violence at work in the judgment. For example, Athanassoulis's critique of Brown involves offering a re-description of sado-masochism that emphasises calm, control and professionalism, and has very little in common with Lord Templeman's depiction of wild excess:

57 Stoler (2002, p. 43).

58 Hutchinson (I999, pp. 84-86).

59 Euripides (2006, line 260).

60 Barnett (I998, p. I53).

6I For a discussion of these classical rhetorical devices applied in a different modern legal context, see Harrington (2009) and Booth (2004).

62 See also Fitzpatrick (200I, p. 78).

63 See the discussion of the Court of Appeal judgments of Dica and Konzani in the next section. 
"Sado-masochistic practises are governed by rules and boundaries set up by the masochist, who controls them by the use of special passwords. The masochist's consent is specific and mapped out in detail prior to any activity." ${ }^{4}$ Athanassoulis wants to criticise the legal position on sadomasochism by inscribing the acts in question with law, normativity, boundedness, predictability. His own rhetoric deploys such words as "governed", "rules", "boundaries", "control", "passwords". ${ }^{65}$ Although this legalistic re-description is aimed at refuting the House of Lords' moralism and drawing attention to the excessive preoccupation in their Lordships' narratives with the extreme dangers of SM, the narrative effect is actually very similar, since it implies the same moral hierarchy between the civilised and the savage. Athanassoulis himself accepts that activities that cannot be aligned with law in this way may justifiably be criminalised. Similarly, consider the Court of Appeal judgment of Wilson, ${ }^{66}$ in which the rhetoric of cilvilised/savage is used to achieve the opposite result to that achieved in Brown. In that case there was no question as to whether Mrs Wilson had consented to being branded by her husband (she had), nor as to whether Mr Wilson had intended to inflict bodily harm (he had). The only question was whether he was entitled to rely on her consent as a defence to a s.47 assault charge or whether, as the trial judge had directed, following Brown, the branding was a crime irrespective of consent as a consequence of it involving the intentional infliction of bodily harm. The Court of Appeal decided that there was no criminal offence committed, reading the branding as non-violent, the motivation as non-sexual, and that given these readings, the criminal law has no place in private marital affairs. Other critics have commented that the distinguishing of Brown by the Court of Appeal in Wilson shows blatant heteronormativity: since Mr Wilson had intended to inflict actual bodily harm and that there was evidence on which the Court could have found a sexual motive, all that separated the branding in the two cases was that the latter took place in the traditionally private domestic setting of a lawful marriage (Khan, 2009, pp. I08 - I09). However, further to these observations, Russell LJ's rhetoric in Wilson shows up another way in which the repudiation of savagery operates to lend authority to legal decisions. Like the characterisation of sado-masochism by Athanassoulis and by Stychin, Russell LJ's emphasis of the predictability of $\mathrm{Mr}$ and Mrs Wilson's actions - her "instigation" of the branding presumably implies that there was little chance of escalation - is itself a refutation of savagery. Also, Russell LJ's refusal to consider the possibility that the branding might have led to even more serious infection or injury exposes a further critique of the speculative imaginings of their Lordships in Brown, and of Lord Jauncey's assertion that "[w]hen considering the public interest potential for harm is just as relevant as actual harm". ${ }^{67}$ In Wilson, Russell LJ took the view that such generalising reasoning was itself excessive because if applied too widely, it would also threaten to criminalise activities that they did not intend to condemn. Therefore in contrast to Brown, there is no speculation in Wilson as to the possible dangers of further infection or harm. Furthermore, rather than the general prohibition of intentionally inflicted bodily harm favoured in Donovan, Boyea and Brown, Russell LJ preferred that "the law should develop upon a case by case basis rather than upon general propositions". ${ }^{68}$ Although previous commentators may be right to say that on the point of law Russell LJ misapplies Brown, nevertheless the two judgments may be read as consistent on a

64 Athanassoulis (2002, p. I48).

65 This insistence on the regulatory effectiveness of SM code words and scripts is a rhetorical device also used to similar effect by Stychin (I995, p. I22).

66 [I997] QB 47.

67 [I993] 2 All ER 75 at 9I.

68 [I997] QB 47 at 50. 
rhetorical level. ${ }^{69}$ Both cases make a claim to legitimacy through a repudiation of savagery, but whereas in Brown this was achieved by emphasisng the harms inflicted and speculating on how much worse these could have been, Russell LJ implicitly includes the dangers of exactly that sort of excessive rhetoric in emphasising the civilised nature of Mr and Mrs Wilson's behaviour. Russell LJ's insistence that the criminal law should apply on a case by case basis acknowledges that there is a danger that, if applied excessively (i.e. to the point at which there may be genuine cause to doubt the effects of its application, such as the criminalisation of marital privacy), the law may itself be in danger of become compromised by, and implicated in, savagery.

\section{Consent in non-violent sexual behaviour}

The recent judgments on reckless HIV transmission have provided further material for debate on the significance of sexualisation in the distinction between savage and civilised in legal rhetoric. In the Court of Appeal decision of Dica, Judge LJ held that in cases where there was no obvious violence or intention to inflict bodily harm, then consent would be available, and it would be a question of fact as to whether the defendant (D) was reckless as to its infliction and also to whether the victim (V) consented to the risk of harm. Judge LJ asserts that consensual intercourse without intending to spread infection is "not indulging in serious violence for the purposes of sexual gratification", ${ }^{70}$ and therefore if the victim did in fact consent to the risk of HIV transmission (and that would be a question for a jury ${ }^{7 \mathrm{I}}$ ) then that consent provides a good defence for the defendant. Although HIV is very clearly treated as an example of 'bodily harm', the way in which it is inflicted (through transmission of bodily fluids) seems to constitute a new distinction from Brown, Donovan and Boyea, inasmuch as it involves no 'serious violence'. However, despite the apparently greater sympathy for the consent defence expressed in Dica and Konzani for bodily harm inflicted in this way, the same discursive repudiation of the savage through sexualisation and interconnecting race and gender narratives are discernable here also. It has been noted by other critics (namely Monk, 2009) that in Dica, Judge LJ conspicuously goes out of his way to disassociate lawful consent to a risk from sexual motivation. I would add that this is not merely, as Monk argues, a symptom of judicial discomfort on the topic of sexually motivated risky behaviour, but also a sign of the far-reaching impact of the association between non-normative sexuality and savagery in the Lords' rhetoric in Brown. Judge LJ held that juries are to consider how 'likely' it was that $\mathrm{V}$ intended their consent to sexual intercourse also extended to the risk of HIV transmission (and thus to the risk of bodily harm). Judge LJ gives two examples of lawfully and consensually running the risk of HIV transmission for non-sexual reasons, and pretty obscure ones at that: a Roman Catholic couple where one party is HIV positive, who are morally "unable" to use contraception, and a young couple, again where one or both parties is HIV positive, desperate to have a child of their own. ${ }^{72}$ These non-sexual motivations for running the risk of HIV transmission would be lawful provided that the consent was specifically 'informed'. However, it also leaves open the theoretical possibility that a jury might regard that $\mathrm{V}$ had consented to the risk of HIV transmission in the absence of disclosure simply because s/he was well informed about the general risks of HIV, perhaps knew something about D having had, say, a partner who was HIV-positive, and demonstrated a readiness to run

69 As a legal point, other commentators have argued that in interpreting Brown thus, Russell LJ was right in principle, but at the same time fundamentally wrong on the interpretation of Brown (Roberts, I997, p. 33).

70 [2004] EWCA Crim I I03 (CA) at para. [47].

7 I [2004] EWCA Crim II03 (CA) at para. [32].

72 [2004] EWCA Crim Iio3 (CA) at para. [49]. 
that risk for no better reason than for sexual gratification. ${ }^{73}$ It may have been this possibility that led Judge LJ in the following case of Konzani to restrict it even further by drawing a formal distinction - never previously recognised by the courts in cases charged under the Offences Against the Person Act I86I - between general and informed consent: "There is a critical distinction between taking a risk of the various, potentially adverse and possibly problematic consequences of sexual intercourse, and giving an informed consent to the risk of infection with a fatal disease." 74 Judge LJ then adds: "Her consent is not properly informed, and she cannot give an informed consent to something of which she is ignorant."75

Judge LJ's stated aim in making explicit the legal requirement of informed consent was better to reflect modern concerns about individual autonomy, and indeed many legal theorists do accept that respect for individuals' autonomy as moral agents is the basis on which the value of informed consent rests. ${ }^{76}$ However, if a concern for autonomy was the complete answer, it is legitimate to ask why, unlike in Dica or the other cases in which V is held to have actively consented to a risk, Judge LJ does not leave any room at all for $\mathrm{D}$ to argue that $\mathrm{V}$ could have and should have taken responsibility for herself in the absence of specific disclosure? Konzani goes well beyond criminalising only those defendants that intentionally deceive $\mathrm{V}$ by concealing their HIV status. Consent is also denied to the non-disclosing defendant even if he correctly believed that $\mathrm{V}$ had consciously taken a calculated risk, knowing the risks of HIV transmission in general terms and knowing that D had practised unsafe sex or needle-sharing in the past. Admittedly, in such a case $\mathrm{V}$ would lack the information that would ensure a fully informed decision. But previously to this case, the courts had never insisted on specific disclosure of the full magnitude of a risk before allowing consent or presumed consent to excuse unintentionally inflicted bodily harm.77 It cannot be likely that the victims of Jones or Aitken for example, having had the specific risks explained to them in advance, would have given 'informed consent' to the horseplay deemed to be lawful in those cases. What separates the Konzani formulation from these cases of lawfully inflicted bodily harm is not V's opportunity to make an informed decision to take a risk, but rather the sexual motivation of the defendant. It is difficult to read Judge LJ's judgment without noticing the stress that he lays on Feston Konzani's libidinous motivations, described in gratuitously graphic sexual terms: "[he] ejaculated inside of her". ${ }^{8}$ The implication that I draw here is that Lord Templeman's distinction between civilised and uncivilised behaviour continues to inform the modern judicial attitude towards sexual motivation, leading the courts to adopt a different standard when the motivation for the dangerous behaviour is clearly sexual gratification, compared to those cases where no sexual motivation was accepted. Where the motivation for running a risk is merely sexual, as opposed to, say, religious, it is considered to be feckless, unproductive and not conducive to a civilised society. There are historical parallels to be drawn here both in moral and economic terms. The libidinous body - be it the unruly slave of colonial settlements who lust after White women and allow fertile land go to waste or the sexually

73 See Weaitt (2005, p. I 28): "It is submitted that where a person consents to sexual intercourse with knowledge of these facts, and becomes infected, the defence should be available because in each of these cases that person is aware of the risk of transmission."

74 [2005] EWCA Crim 706 (CA) at para. [4I].

75 [2005] EWCA Crim 706 (CA) at para. [42].

76 See Maclean (2009, pp. 4I-45). Maclean considers and rejects challenges to this position by J. S. Taylor (who argues that informed consent is based on "concern for human well-being”) and N. C. Manson and O. O'Neill (who use Kant to argue that informed consent is premised instead on the duty to be trustworthy).

77 As decided for example in Wilson [I997] QB 47, $R$ v. Jones (Terence) (I986) 83 Cr App R 375, and $R v$. Aitken and others [I992] I W.L.R. I006.

78 [2005] EWCA Crim 706 (CA) at para. [8]. 
reckless modern man - is directed only towards death, and requires a civilising authority to turn it towards a positive end. ${ }^{79}$ The tendency in the courts to associate bodily harm inflicted for sexual gratification with uncivilised, savage masculinity (as discussed above in relation to Brown, Donovan and Boyea) means that even in the absence of obvious violence, sexual gratification as a motivating factor must be treated with a caution not otherwise deemed necessary. Konzani formalises this alignment with Brown, etc. in the sense that, given how unlikely it would be for a person to give explicit informed consent specifically to the risk of HIV transmission except where there is a very good reason to do so (i.e. a non-sexual one), the informed consent requirement effectively prevents $\mathrm{D}$ from relying on the defence.

\section{Problematising consent in legal rhetoric through a feminisation of the 'victim'}

In the first section I suggested that one of the ways in which savagery is distinguished from the civilised is by dissociating the victim of savagery from savagery itself. In The Tempest, Miranda, the virgin adolescent daughter of colonial settler Prospero, has traditionally been dissociated from the savage by removing any reference in her own speech to Caliban's deviant sexuality. As we saw in the first section, the effect of thus removing Miranda from the discourse of savagery is that the audience can participate in the condemnation of the 'violation' without worrying that the wouldbe victim might herself already be corrupted. To put it in modern legal terms, it avoids having to consider the troubling question as to whether Miranda might have consented to Caliban's sexual advances. Considering that the basis of Prospero's authority to rule depends upon his maintaining a plausible moral distinction between the civilised and the savage, such an idea carries potentially disastrous consequences. Caliban may be emasculated by the domination of Prospero, but he nonetheless represents a masculinity that poses a danger to civilised femininity, the latter being vulnerable on account of her supposed innocence. The modern criminal legal position inherited from Donovan and Brown follows this same logic, and this being so it might be imagined that the intentions, capacity and competence of the 'victim' - indeed the very question as to whether that victim consented at all - would be regarded as irrelevant. But in rejecting the liberal insistence that consent and not moral repugnance at the act in question ought to determine legality (Bamforth, I994), ${ }^{80}$ the courts still devote much energy to the status and quality of the victims' consents. Why should this be? The answer seems to be that, in seeking to achieve plausibility for distinguishing sexually motivated violence from bodily harm inflicted for 'good reasons', the courts have also found it necessary to supplement their moralism with a further narrative that speaks more directly to liberal concerns about consent. Hence, as well as condemning 'cruel violence', judicial rhetoric undermines the quality and reliability of the victim's consent, associating the victim of an illegal (consensual) act with feminine weakness. This genderising of consent and of the capacity of a person to give valid consent has been identified elsewhere in legal narrative. Keywood, for example, has argued that the "apparently inexorable identification of women with their bodies" (and hence with sensibility rather than with reason) has contributed to legal reasoning in which the courts have found female patients to lack the competence necessary to refuse proposed medical care. This section therefore forms the second part of my reading of the judicial rhetoric in these cases as a production of law through the repudiation of savagery. ${ }^{8 \mathrm{I}}$

This is a narrative that is discernable in the judicial rhetoric, which seeks to strengthen the association between the defendant and the savage by drawing attention away from signs that a

79 For a discussion of the historical colonial economic parallels, see generally Wood (2003).

80 Bamforth (I994). See also Erin (2007, pp. 246ff). For a different view of the liberal approach to consent and bodily harm, see Weaitt (2005, pp. I28-29).

8I Keywood (2000, p. 502). 
'victim' willingly participated in a harmful non-normative act. This is a rhetorical turn that ensures that, contrary to the liberal perspective, the defendant and the victim are clearly distinguished in moral terms. Thus the condemnation and punishment of malign or deviant masculinity makes 'moral' sense because the victim herself may be positioned on the side of the civilised: redeemable, albeit temporarily compromised. Since consent is a tricky matter of fact, the discernable gender stereotypes of the decisive deviant masculine and the innocent wavering feminine provide a supplementary rhetorical weapon in the armoury of legal moralism. The judgments of Donovan, Boyea and Brown each give the impression that the criminal perversion and excessiveness of the defendant's motivation is more reliably identifiable than is the extent of the knowledge, understanding and willingness of the victim. In this way, the victim (whether male or female) is identified with the vulnerable, compromised feminine voice that we described above being suppressed by legal discourse: not competent to speak decisively about her own desires or needs, relying instead on the protection of authoritative masculinity (law) from deviant influences.

Take the appeal of Donovan, for example, who was very reluctantly acquitted because, although his beating of a seventeen-year-old girl would have been a crime irrespective of consent so long as bodily harm was a "probable consequence", the trial judge had erroneously not presented that as a question to the jury, asking them instead to convict or acquit on the basis of whether or not the victim consented. ${ }^{82}$ The preference for the Crown's submission that consent should be irrelevant may be explainable by the fact that it makes a very large area of uncertainty - namely the victim's own desires and intentions - an irrelevance, the only relevant thing being the deviance of the defendant. It is clear from Swift J's judgment that the issue of the victim's consent was a difficult one since the evidence was conflicting. First, there is an overheard private telephone conversation where "there was talk between the appellant and the prosecutrix which left no doubt that she had expressed her willingness to submit herself to the kind of conduct to which he was addicted". ${ }^{83}$ Next, we learn that the girl "did not take seriously" Donovan's opening line when they met at Marble Arch, "Where would you like to have your spanking, in Hyde Park, or in my garage?", and then that she returned home later that night "looking pale and ill", reporting to the effect that she had been "compelled or induced by fear" to submit to Donovan. ${ }^{84}$ We get the impression of a girl who does not know what she wants, who wavers between yes and no, whose own testimony is frustrating and unreliable at best, and an unsound basis on which to base a legal judgment. She is rather to be pitied than taken seriously as a witness to her own degradation, and this impression is further underlined by the fact that she is referred to by Swift J only as a "girl" and therefore as a mere child despite in fact being seventeen. In contrast, Donovan himself is presented as unwavering in his commitment to his perversion. As I have already said, his very first line upon meeting the victim unambiguously announced his intensions. Swift J further elaborates that he was "addicted to a form of perversion" 85 which involved violence, and it was "not in dispute that the motive of the appellant was to gratify his own perverted desires" ${ }^{86}$ Like Puar's description of the reaction in the US to 9/II as "homonationalism", I want to draw attention here to an oppressive gender narrative in the judicial response to consensual violence. In this particular case the jury found that the victim did not consent and the defendant's conviction was quashed due to the trial judge's misdirection. However, the legacy of Swift J's judgment is that in future cases the

82 [I934] $2 \mathrm{~KB} 498$ at 5 IO.

83 [I934] 2 KB 498 at 503.

84 [I934] 2 KB 498 at 503.

85 [I934] 2 KB 498 at 502.

86 [I934] 2 KB 498 at 509. 
reprehensibility of D's actions and motives would be a more reliable basis for convicting disgusting behaviour than V's consent or lack of.

A similar analysis of Boyea ${ }^{87}$ and Brown also lends support to reading a gender narrative into the determination of the legal issue. Boyea involved a male defendant appealing against a conviction for a sexually motivated assault on one Miss Collins. Here again both V's consent and the criminality of D's act were at issue and as in Donovan, the question of consent was frustratingly undecidable. Glidewell Lj's judgment continually draws attention to the unreliability of both parties' testimonies on the question of consent, and particularly to the problems encountered in gaining a consistent account from the victim herself. For one thing, "Both parties were under the influence of alcohol to a very considerable extent", and the Court approved the trial judge's warning to the jury that, on the subject of Miss Collins's evidence: "If you come to the conclusion that she had drunk more than she told you about when giving evidence and that that was not because she genuinely cannot recall what she did drink but was a deliberate lie, you would have to consider whether that undermines your confidence in the rest of her evidence or not." 88 On the other hand, the criminality of the defendant's act was clear, since it was without doubt "an assault intended or which is likely to cause bodily harm" and being "accompanied by indecency" was committed for no good reason. ${ }^{89}$ Returning to Brown once again, although the case involved male homosexual violence, the gender narrative with respect to this issue of the victim's consent is clearer still. Although as is well known Lord Templeman's judgment was always based on his view that sadomasochism was criminal irrespective of consent, he nevertheless devotes a large amount of time to questioning the validity of the consents of the victims. Lord Templeman asserts that the consents of the victims were "dubious or worthless". In support of this he points out that whereas the appellants were "middle-aged men", the victims were "youths, some of whom were introduced to sadomasochism before they attained the age of $2 \mathrm{I}$ " 90 and moreover, "drink or drugs were employed to obtain consent and increase enthusiasm". ${ }^{\text {I }}$ Lord Jauncey similarly warns that "the possibility of proselytisation and corruption of young men is a real danger", 92 implying that the older men used devious strategies for seducing the suggestible and weak-minded. As in Boyea and Donovan, the significance of these statements regarding the quality of the victims' consents is that it further reveals the rhetorical work being done throughout the judgments to persuade that there are certain acts that cannot be accommodated in a civilised society. It adds a supplementary rhetorical layer to the narrative of the perverted masculine intent of the defendants as a more reliable basis for judgment than the emasculated, feeble consents of the victims.

Finally, the HIV transmission cases may equally be read as tapping into a narrative of innocence. The special status accorded to sexual gratification as a motivation for inflicting bodily harm applied in these most recent cases means that no matter how well informed $\mathrm{V}$ is in general terms of the risks of infection or even of D's own previous sexual behaviour, the validity of consent does not depend on V's knowledge, but simply on D's disclosure. I suggested above that the effect of this decision is to make it very difficult for a defendant to raise the defence of consent where the motivation for his behaviour was merely sexual gratification and that $\mathrm{D}$ will face prosecution even when $\mathrm{V}$ was known to be in a position fully to take responsibility for her own protection due to her

\footnotetext{
87 (I992) I56 J.P. 505

88 (I992) I56 J.P. 505 at 507-508.

89 (I992) I56 J.P. 505 at 5 I3.

90 [I993] 2 All ER 75 at 82.

9I [I993] 2 All ER 75 at 83.

92 [I993] 2 All ER 75 at 92.
} 
knowledge about HIV generally and about D's past risky behaviour. With this in mind, it seems to me appropriate to draw certain implications from Judge Lj's decision also to go to some lengths to establish that Feston Konzani's first victim (referred to as 'DH') did not have any such knowledge, either about Konzani himself, or about the risks of sex or HIV in general. For example, Judge LJ reminds us that this girl was just fifteen years old and furthermore was a virgin until Konzani met her. He also includes in his judgment an extract from the girl's cross-examination by the prosecuting barrister in which it was established that she was not even aware that there was an "Aids problem in Africa", the continent from which Konzani had come, and would be deported back to after completing his jail term. ${ }^{93}$ Although in very narrow terms the ruling in Konzani that D always bears a duty to disclose his HIV infection means that these comments about the girl's general ignorance are strictly obiter, they nevertheless play an important role in the judgment, namely in shoring up the persuasiveness of his appeal to the cultural belief that HIV transmitted for no better reason than the defendant's own sexual gratification is an especially reprehensible thing to do. Showing that DH was indeed profoundly ignorant, both of HIV/Aids in general and of Konzani's infection in particular, underlines for an audience that HIV - more than other sorts of bodily harm - is as much about information as it is about harm, and about the gross imbalance of informational power between the parties in this regard. Although Judge LJ also reveals that the other two women infected were considerably older and more experienced than DH and certainly old enough to know better, references to their 'devastation' invites the reader to identify emotionally with them as well, and to conclude that even if the victims might have exercised more effective self-protection, Konzani cynically took advantage of his informational status for no good reason, and thus poses a danger to vulnerable young women everywhere.

\section{Conclusion}

This article has sought to offer a critique of judicial rhetorical strategies of persuasion, reading across from post-colonial literary criticism to locate a narrative of savagery and its repudiation in modern legal judgment and its claims to authority. My discussion has aimed to show how existing critical engagements with the law may be enriched by highlighting the interweaving themes of gender, race and sexuality, themselves productive of a richer notion of the savage 'other' whose violence and unproductiveness must be kept apart from law. The much-commented-upon judicial unease with regards to sexuality as a motivating factor for engaging in dangerous activity is a central and crucial aspect of these narratives, which, in order that a distinction may be maintained between the civilised and the savage, is combined in rhetoric with anxieties about unrestrained violence, and the dangers that it poses for the corruption and degradation of the innocent and vulnerable. These are the elements of a multidimensional critical approach that have been applied by scholars in various contexts, and applied here to legal rhetoric to suggest ways in which judicial language, which might otherwise only be read as homophobic or erotophobic, also show further intertextual political and moral significance. I would stress finally that the critical collaboration that I suggest here is possible between literature and legal scholarship comes from a specific concern to bring a particular approach to bear on the judgments explored in this article, and I do not mean to imply that the wider themes of interest for interdisciplinary work could not be addressed with reference through different literary or legal sources.

93 "Q: And were you aware that there is an Aids problem in Africa?

A: Not really, no.

Q: What did you know about him before you agreed to have sex with him?

A: Not much ..." (quoted by Judge LJ at p. 20I (para. [I3])). 


\section{References}

athanassoulis, Nafsika (2002) 'The Role of Consent in Sado-masochistic practices', Res Publica 8(2): I4 I- 55 .

Bamforth, N. (I994) 'Sado-masochism and Consent', Criminal Law Review (Sept): 66 I-64. Barnett, H. (I998) Introduction to Feminist Jurisprudence. London and Sydney: Cavendish Publishing. BERSANI, Leo (I988) 'Is the Rectum a Grave?' in Crimp (I998), I97-222.

воотн, Wayne C. (2004) The Rhetoric of Rhetoric. Malden, MA and Oxford: Blackwell Publishing. CRANOR, Carl F. (I979) 'Legal Moralism Reconsidered’ Ethics 89(2): I47-64.

CRIMP, Douglas (ed.) (I988) Aids: Cultural Analysis, Cultural Activism. London and Cambridge, MA: The MIT Press.

Darian-SMith, Eve (I995) 'Rabies Rides the Fast-train: Transnational Interactions in Post-colonial

Times', Law and Critique 6(I): 75-94.

DEAn, T. (2000) Beyond Sexuality. Chicago and London: University of Chicago Press.

DERRIDA, J. (I992) 'Force of Law: The Mystical Foundations of Authority' in D. Cornell, M. Rosenfeld

and D. Carlson (eds), Deconstruction and the Possibility of Justice. London and New York: Routledge, 3-67.

Dyмкоwsкi, Christine (ed.) (2000) The Tempest. Cambridge: Cambridge University Press.

ERIN, C. (2007) 'The Rightful Domain of the Criminal Law' in C. ERIN AND S. OST, the criminal justice system and health care. oxford: oxford university press, 237-56.

EURIPIDES, (2006) The Bacchae and Other Plays. John Davie, trans. London: Penguin Classics.

Fanon, Franz (1963) The Wretched of the Earth. Constance Farrington, trans. New York: Grove Press.

fanon, Franz (I986) Black Skin, White Masks. Charles Lam Markmann, trans. London: Pluto Press.

FeInberG, Joel (I984) Harm to Others. New York: Oxford University Press.

FitzPatrick, Peter (I999) 'Passions out of Place: Law, Incommensurability and Resistance' in E. Darian-

Smith and P. Fitzpatrick (eds), Laws of the Postcolonial. Michigan: University of Michigan Press, I999, 39-69.

FitzPatrick, Peter (200I) Modernism and the Grounds of Law. Cambridge: Cambridge University Press. GILman, Sander L. (I988) 'Aids and Syphilis: The Iconography of Disease' in Crimp (I988), 87-I07. GuRnham, David (2009) Memory, Imagination, Justice. Farnham: Ashgate.

HARRINGTON, John (2009) 'Migration and Access to Health Care in English Medical Law: A Rhetorical Critique', International Journal of Law in Context 4(4): 3I5-35.

hulme, Peter (I986) Colonial Encounters: Europe and the Native Caribbean, I492-I797. London and

New York: Methuen.

Hutchinson, Darren Lenard (I999) 'Ignoring the Sexualisation of Race: Heteronormativity, Critical

Race Theory and Anti-racist Politics', Buffalo Law Review 47(I): I-I I6.

KeYwood, Kirsty (2000) 'My Body and Other Stories: Anorexia Nervosa and the Legal Politics of Embodiment', Social and Legal Studies 9(4): 495-5I3.

KHAN, U. (2009) 'A Woman's Right to be Spanked: Testing the Limits of Tolerance of SM in the Sociolegal Imaginary', Law and Sexuality i 8: 79-I I9.

Lamming, George (2004) 'A Monster, a Child, a Slave' in Peter Hulme and William H. Sherman (eds), The Tempest: William Shakespeare. Sources and Contexts, Criticism, Rewritings and Appropriations. New York and London: Norton, I48-68.

maclean, Alasdair (2009) Autonomy, Informed Consent and Medical Law: A Relational Challenge. Cambridge: Cambridge University Press.

mannoni, O. (1956) Prospero and Caliban: The Psychology of Colonization. Pamela Rowesland, trans. London: Methuen.

MARTIN, Emily (I994) Flexible Bodies: Tracking Immunity in American Culture - from the Days of Polio to the Age of Aids. Boston, MA: Beacon Press. 
MONK, Daniel (2009) 'Reckless Trials?: The Criminalization of the Sexual Transmission of HIV', Radical

Philosophy I56: 2-6. Online: http://www.radicalphilosophy.com/default.asp?channel_id=2I87 editorial_id=2820I [accessed 4/ro/ro].

moran, Leslie J. (I996) The Homosexual(ity) of Law. London and New York: Routledge.

NiLsson, L. (1985) The Body Victorious. New York: Delacorte.

PUAR, Jasbir K. (2007) Terrorist Assemblages: Homonationalism in Queer Times. Durham, NC and London:

Duke University Press.

RAFField, P. (2008) '"Terras Astrae Reliqui": Titus Andronicus and the Loss of Justice' in P. Raffield and

G. Watt (eds.), Shakespeare and the Law. Oxford: Hart Publishing, 203-220.

RAMAGE, S. (2008) 'Witchcraft, Lollardy and the Meaning of "Evil”, Criminal Lawyer I87: 9-10.

ROBERTS, Paul (I997) 'Consent to Injury: How Far Can You Go?' Law Quarterly Review I I3: 27-35.

SAID, Edward (I978) Orientalism. New York: Pantheon Books.

SAID, Edward (I994) Culture and Imperialism. London: Vintage.

SCHINDLER, L. W. (I988) Understanding the Immune System. Washington, DC: Department of Health and

Human Services.

ShaKeSPEARE, William (I954) The Tempest. Frank Kermode (ed.), Arden Shakespeare, 5th edn. London:

Methuen.

ShaKesPeare, William (2000) The Tempest. Alden T. Vaughan and Virginia Mason Vaughan (eds.),

Arden Shakespeare, Third Series, 3rd edn. London: Thomas Nelson \& Sons.

sithamparanathan, A. (2002) 'Noble Art of Self-defence or Unlawful Barbarism?', Entertainment Law

Review I3(8): I83-87.

STOLER, Ann (2002) Carnal Knowledge and Imperial Power: Race and the Intimate in Colonial Rule. Berkeley,

CA: University of California Press.

STYсніn, Carl F. (I995) Law's Desire: Sexuality and the Limits of Justice. London and New York: Routledge. treichler, Paula A. (I988) 'Aids, Homophobia and Biomedical Discourse: An Epidemic of

Signification' in Crimp (I988), 3 I-70.

weaitT, Matthew (2005) 'Criminal Law and the Sexual Transmission of HIV: $R$ v. Dica', Modern Law

Review 68(I): I2 I-34.

wood, E. (2003) Empire of Capital. London and New York: Verso.

\section{CAMBridge JDUANALS}

